Teresa BRZEZIŃSKA-WÓJCIK

Ewa SKOWRONEK

Andrzej ŚWIECA

Marta Jolanta JÓŹWIK

Uniwersytet Marii Curie-Skłodowskiej w Lublinie

\title{
STAN BADAŃ NAD TURYSTYKĄ W REGIONIE LUBELSKIM
}

\section{Wprowadzenie}

Problematykę wykorzystania zasobów środowiska geograficznego regionu lubelskiego na potrzeby turystyki podejmowano $\mathrm{w}$ opracowaniach różniących się zakresem i sposobem ujęcia. Próbę podsumowania problematyki badawczej, także w ujęciu przestrzennym, stanowią opracowania A. ŚWIECY i in. (2012), A. ŚWIECY i T. BRZEZIŃSKIEJ-WÓJCIK (2013), zaś w zakresie dydaktyki - A. ŚWIECY i T. BRZEZIŃSKIEJ-WÓJCIK (2010).

Region lubelski (Lubelszczyzna), utożsamiany aktualnie z województwem lubelskim jest zróżnicowany pod względem fizjograficznym. Na tle innych wyróżnia się niewielkim stopniem przekształcenia antropogenicznego. Zachowały się $\mathrm{w}$ nim tereny o unikatowych walorach przyrodniczych i kulturowych, które stwarzają potencjalne możliwości rozwoju ruchu turystycznego (SKOWRONEK, WOJCIECHOWSKI, ŚWIECA 2006, BRZEZIŃSKA-WÓJCIK, ŚWIECA, TUCKI 2009).

W niniejszym opracowaniu zamieszczono przegląd publikacji, w których uwarunkowania rozwoju turystyki na Lubelszczyźnie przeanalizowano w oparciu o konkretny warsztat metodyczny. Zasadnicza część pracy poświęcona jest różnorodnym aspektom badań prowadzonych przez pracowników Zakładu Geografii Regionalnej i Turyzmu Wydziału Nauk o Ziemi 
i Gospodarki Przestrzennej UMCS w Lublinie. Uwzględniono m.in. zagadnienia dotyczące możliwości turystycznego wykorzystania zasobów przyrodniczych i kulturowych regionu lubelskiego, oceny atrakcyjności przestrzeni turystycznej, jej percepcji przez użytkowników, a także typologii funkcjonalnej przestrzeni oraz regionalizacji turystycznej. Zwrócono również uwagę na wyniki badań aplikacyjnych w ramach projektów i ekspertyz na zlecenie jednostek administracyjnych i rządowych.

\section{Aspekty metodyczne w badaniach nad turystyką}

Uniwersytecki ośrodek geograficzny w Lublinie funkcjonuje od roku 1945. Prace związane z turystyką na kierunku "geografia” pojawiły się w roku 1956 (WILGAT 1956). W kolejnych latach powstały nieliczne opracowania naukowe, analizujące warunki rozwoju różnych form turystyki w regionie (NOWACKA 1984) oraz prace o charakterze informacyjnym i popularnonaukowym (WOJCIECHOWSKI 1976, NOWOSAD 1989). W tym okresie, z punktu widzenia metodologii oraz badań geograficzno-turystycznych, bardzo istotne były opracowania prof. Tadeusza Wilgata, analizujące zagadnienie zabezpieczenia dla celów rekreacyjnych Pojezierza Łęczyńsko-Włodawskiego (WILGAT, red. 1963), będącego przedmiotem wycieczek geograficznych (WILGAT 1956), jak również kwestię strefy wypoczynkowej miasta Lublina w promieniu około 50 km (WILGAT 1962) oraz Płaskowyżu Nałęczowskiego i Roztocza (WILGAT 1971). Na uwagę zasługuje również opracowany w latach 60. XX w. Projekt inwentaryzacji woybranych szlaków turystycznych Polski Południowo-Wschodniej (ANASIEWICZ i in. 1967). Istotne znaczenie w wymienionych opracowaniach miały załączniki kartograficzne, na których wyodrębniono obszary o korzystnych warunkach dla turystyki i rekreacji.

Działalność badawczą i publikacyjną zintensyfikowało uruchomienie specjalności „geografia turyzmu” (w roku 2003) na kierunku studiów "geografia". W procedurze badawczej zjawisk turystyczno-rekreacyjnych znalazły zastosowanie różne metody: inwentaryzacja terenowa, waloryzacja, wielowymiarowa analiza porównawcza, procedura SWOT, kartograficzno-statystyczne, funkcjonalna typologia przestrzeni wypoczynkowej i turystycznej oraz regionalizacja turystyczna. Niejednokrotnie posługiwano się także metodami zaczerpniętymi z nauk społecznych (wywiad, badanie ankietowe, wywiad kwestionariuszowy). 
Opierając się na metodzie inwentaryzacji terenowej analizowano możliwości rozwoju różnych form turystyki w regionie lubelskim. Przykładem są prace zawierające inwentaryzację zasobów turystyczno-rekreacyjnych miast - Lublin, Krasnobród, Zwierzyniec, i gmin - Dołhobyczów, Dorohusk, Dubienka, Hanna, Horodło, Hrubieszów, Kodeń, Lubycza Królewska, Mircze, Ruda Huta, Rokitno, Sławatycze, Terespol, Wola Uhruska, Ulhówek, Włodawa (KRUKOWSKA 2004, BRZEZIŃSKA-WÓJCIK, ŚWIECA, OSMÓLSKA 2006, ŚWIECA, KRUKOWSKA, BRZEZIŃSKA-WÓJCIK 2008, ŚWIECA, BRZEZIŃSKA-WÓJCIK, KOCIUBA 2009, BRZEZIŃSKA-WÓJCIK, SKOWRONEK 2009, ŚWIECA, BRZEZIŃSKA-WÓjCIK 2009). Przeprowadzono również inwentaryzację dziedzictwa kulturowego w kontekście możliwości jego turystycznego wykorzystania (SKOWRONEK, WOŁOSZYN 2004). Osobliwości geologiczne oraz geomorfologiczne zostały zinwentaryzowane $\mathrm{w}$ celu oceny możliwości ich wykorzystania w geoturystyce (BRZEZIŃSKA-WÓJCIK, ŚWIECA, KOCIUBA 2007, ZGŁOBICKI, BRZEZIŃSKA-WÓJCIK, GAWRYSIAK, HARASIMIUK 2007, BRZEZIŃSKA-WÓJCIK 2009, BRZEZIŃSKA-WÓJCIK, HARASIMIUK 2009, KRĄPIEC i in. 2011).

Wykorzystując metodę bonitacji punktowej podejmowano prace zmierzające do oceny atrakcyjności środowiska całego Pojezierza Łęczyńsko-Włodawskiego na potrzeby turystyki (KRUKOWSKA 2009, KRUKOWSKA, KRUKOWSKI 2009) lub tylko wybranych jednostek administracyjnych tego regionu gmin powiatu łęczyńskiego, gminy Ludwin (TUCKI 2004), a także miasta Lublin (BRZEZIŃSKA-WÓJCIK, ŚWIECA, ROMAŃSKA 2009). Metodę bonitacji punktowej zastosowano także do oceny atrakcyjności obiektów dziedzictwa geologicznego Roztocza w kontekście ich udostępnienia geoturystycznego (KRĄPIEC i in. 2011).

Duży udział w dorobku ośrodka lubelskiego mają prace, w których wykorzystywano metodę wielowymiarowej analizy porównawczej. Zastosowana metoda umożliwia wymierne porównanie ze sobą obiektów wielocechowych, przy wykorzystaniu sumarycznego wskaźnika cech (GOŁEMBSKI, red. 1999). W procedurze badawczej uwzględniono zarówno cały region lubelski (TUCKI 2007a, 2009, ŚWIECA i in. 2012), jak i wybrane subregiony Wyniosłość Giełczewska (BRZEZIŃSKA-WÓJCIK, ŚWIECA 2011), a także wybrane miasta i gminy - Nałęczów i Wojciechów (ŚWIECA, BRZEZIŃSKA-WÓJCIK 2009). W przypadku oceny potencjału turystycznego regionu lubelskiego podstawową jednostką przestrzenną podejmowanych analiz były powiaty lub gminy.

Do oceny zasobów turystycznych wybranych obszarów w oparciu o strukturę potencjału turystycznego wykorzystano procedurę SWOT. Zeb- 
rane dane pozwoliły na opracowanie mocnych i słabych stron oraz szans i zagrożeń rozwoju turystyki w gminie Krasnobród. Umożliwiły również wyodrębnienie wiodących form turystyki w gminie (BRZEZIŃSKA-WÓJCIK, SKOWRONEK 2009).

Zagadnienie percepcji przestrzeni turystycznej miasta Lublina przez różnych użytkowników - mieszkańców, studentów, turystów - realizowano w latach 2004-2005 przy użyciu metod zaczerpniętych z nauk społecznych (BRZEZIŃSKA-WÓJCIK, ŚWIECA, TUCKI 2009, SKOWRONEK, BRZEZIŃSKA-WÓJCIK, KRUKOWSKA 2009, ŚWIECA, SKOWRONEK, BRZEZIŃSKA-WÓJCIK, KRUKOWSKA 2009). Do oceny postaw - postrzegania rozwoju turystyki przez społeczność lokalną w aspekcie ekonomicznym, kulturowym oraz jakości życia na obszarze recepcji turystycznej miejskiej gminy Kazimierz Dolny oraz miejsko-wiejskiej gminy Zwierzyniec (TUCKI, SOSZYŃSKI 2013, TUCKI, SKOWRONEK, KRUKOWSKA 2013) zastosowano model TIAS (ang. tourism impact attitude scale), zaproponowany jako wzorcowy schemat oceny, opracowany przez S.V. LANKFORDA i D. HOWARDA (1994).

W dotychczasowych opracowaniach stosowano również metody statystyczne służące określeniu funkcji turystycznej na Pojezierzu Łęczyńsko-Włodawskim (KRUKOWSKA 2009, KRUKOWSKA, KRUKOWSKI 2009) oraz w Lublinie (ŚWIECA, BRZEZIŃSKA-WÓJCIK 2009). Przeanalizowano również wielkość i zróżnicowanie bazy noclegowej w regionie lubelskim jako determinantę popytu turystycznego (ŚWIECA, KRUKOWSKA, TUCKI 2007, ŚWIECA, BRZEZIŃSKA-WÓJCIK 2009, 2011, TUCKI, SKOWRONEK, KRUKOWSKA 2012).

$\mathrm{Na}$ szczególne podkreślenie zasługuje zastosowanie metod kartograficzno-statystycznych przy wykorzystaniu narzędzi programów ArcView i ArcGIS z zakresu Geograficznych Systemów Informacyjnych (GIS) do oceny atrakcyjności turystycznej Pojezierza Łęczyńsko-Włodawskiego (KRUKOWSKA 2009). Zastosowanie tych nowoczesnych narzędzi umożliwiło zgromadzenie danych przestrzennych i opisowych, odniesionych do sześciobocznych pól podstawowych, jak również uporządkowanie danych w logicznej strukturze i ich modelowanie kartograficzne (KRUKOWSKA, KRUKOWSKI 2009).

Problem typologii funkcjonalnej przestrzeni $\mathrm{w}$ regionie lubelskim podjęto w kilku opracowaniach (KRUKOWSKA, KRUKOWSKI 2009, ŚWIECA, BRZEZIŃSKA-WÓJCIK 2011). Na podstawie wyników analizy użytkowania turystycznego jezior (KRUKOWSKA 2007), a także wykorzystania regionu na potrzeby osadnictwa letniskowego (KRUKOWSKA, ŚWIECA 2008) przeprowadzono na Pojezierzu Łęczyńsko-Włodawskim (KRUKOWSKA, KRUKOWSKI 2009) 
typologię funkcjonalną oraz charakterystykę przemian form kolonizacji turystycznej. Ocena atrakcyjności turystycznej miasta Lublina oraz analiza zasobów turystycznych, natężenia ruchu turystycznego i wybranych elementów zagospodarowania turystyczno-rekreacyjnego była podstawą opracowania typologii funkcjonalnej przestrzeni miasta (ŚWIECA, BRZEZIŃSKA-WÓJCIK 2011 i literatura tam cytowana).

Zagadnienie regionalizacji turystycznej województwa lubelskiego podejmował głównie A. TUCKI (2010c). Podstawą wydzielenia regionów turystycznych była wielkość potencjału turystycznego, tj. zasobów przyrodniczych, kulturowych i społecznych.

W opracowaniach publikowanych $\mathrm{w}$ ośrodku lubelskim podejmowane są także zagadnienia marketingowe. Badania realizowano w krótkich horyzontach czasowych na rzecz polityki turystycznej, samorządów terytorialnych, czy też agend rządowych odpowiadających za sterowanie rozwojem turystyki w regionie. $Z$ punktu widzenia metodycznego, na uwagę zasługuje opracowanie dotyczące roli samorządów lokalnych $w$ rozwoju turystyki (TUCKI, ŚWIECA 2008), znaczenia roli przywództwa w regionie turystycznym na przykładzie Lokalnej Organizacji Turystycznej „Roztocze” (TUCKI 2012) oraz oceny instrumentów promocji gmin Lubelszczyzny z wykorzystaniem metody analizy zawartości stron www (Internet Technology) gmin (TUCKI 2010b).

\section{Problematyka badań nad turystyką $w$ regionie lubelskim}

Przegląd dotychczasowych opracowań opublikowanych przez pracowników Zakładu wskazuje na szeroki zakres podejmowanych problemów, stanowiących następujące nurty badawcze.

Pierwszy z nich obejmuje zagadnienie inwentaryzacji zasobów i potencjału turystycznego. Zinwentaryzowano zasoby przyrodnicze województwa lubelskiego (TUCKI 2007a, BRZEZIŃSKA-WÓJCIK, ŚWIECA, TUCKI 2009), gmin (KRUKOWSKA, SKOWRONEK 2003, 2009, ŚWIECA, BRZEZIŃSKA-WÓJCIK 2009), parków narodowych (SKOWRONEK, ŚWIECA, TUCKI 2005, TUCKI 2010a) oraz regionów: Pojezierza Łęczyńsko-Włodawskiego (ŚwIECA, TUCKI 2007) i Roztocza (BRZEZIŃSKA-WÓJCIK, ŚWIECA, KOCIUBA 2007, BRZEZIŃSKA-WÓJCIK, HARASIMIUK 2009). Oceniono potencjał turystyczny na potrzeby rozwoju różnych form turystyki (TUCKI 2004, 2009, ŚWIECA, KRUKOWSKA, TUCKI 2007, 
ŚWIECA, KRUKOWSKA, BRZEZIŃSKA-WÓJCIK 2008, BRZEZIŃSKA-WÓJCIK, SKOWRONEK 2009, BRZEZIŃSKA-WÓJCIK, ŚWIECA 2011, ŚWIECA 2013). Przeanalizowano funkcjonalne uwarunkowania rozwoju gospodarki turystycznej w regionie lubelskim (TUCKI 2007b), w tym: aktywności władz lokalnych (gmin) w rozwoju turystyki (TUCKI, ŚWIECA 2008), roli lokalnych organizacji w rozwoju przedsiębiorczości i gospodarki turystycznej na przykładzie Lokalnej Organizacji Turystycznej „Kraina Lessowych Wąwozów” (TUCKI, SKOWRONEK, KRUKOWSKA, ŚWIECA 2011).

Drugi nurt dotyczy opracowań poświęconych wykorzystaniu funkcjonalnych zasobów przestrzeni do różnych form turystyki. Przeanalizowano wykorzystanie dziedzictwa kulturowego w rozwoju turystyki (SKOWRONEK 2005, BRZEZIŃSKA-WÓJCIK, ŚWIECA, OSMÓLSKA 2006) ze zwróceniem uwagi na społeczno-ekonomiczne korzyści rozwoju turystyki kulturowej na Roztoczu (SKOWRONEK, WOŁOSZYN 2006). Scharakteryzowano obszary województwa lubelskiego pod względem możliwości rozwoju: turystyki zdrowotnej (TUCKI, HADZIK 2013), zwłaszcza w Krasnobrodzie oraz Nałęczowie (BRZEZIŃSKA-WÓJCIK, SKOWRONEK 2009, SKOWRONEK, KRUKOWSKA, TUCKI 2012), turystyki aktywnej (ŚWIECA 2006, KRUKOWSKA 2012), geoturystyki (ZGŁOBICKI, BRZEZIŃSKA-WÓJCIK, GAWRYSIAK, HARASIMIUK 2007, BRZEZIŃSKA-WÓJCIK 2009, 2012), turystyki konnej (BRZEZIŃSKA-WÓJCIK, BARANOWSKA 2012), turystyki edukacyjnej i przyrodniczej w Roztoczańskim Parku Narodowym i w jego otulinie (ŚwIECA i in. 2013) oraz na Roztoczu (BRZEZIŃSKA-WÓJCIK, ŚWIECA 2014; w druku). Przeanalizowano funkcję turystyczną Pojezierza Łęczyńsko-Włodawskiego (KRUKOWSKA 2007, 2009, KRUKOWSKA, KRUKOWSKI 2009), z uwzględnieniem osadnictwa letniskowego jako jednej $\mathrm{z}$ form turystycznego wykorzystania obszarów wypoczynkowych (KRUKOWSKA, ŚWIECA 2008) oraz miasta Zamościa (SUPERSON, BRZEZIŃSKA-WÓJCIK, CHABUDZIŃSKA, SKULSKA 2013; w druku). Dokonano analizy przestrzeni turystycznej Lublina (ŚWIECA, BRZEZIŃSKA-WÓJCIK 2011), Pojezierza Łęczyńsko-Włodawskiego (KRUKOWSKA 2010), oraz Lubelszczyzny (ŚWIECA i in. 2012), w tym funkcjonalnej typologii przestrzeni turystycznej miasta Lublina (BRZEZIŃSKA-WÓJCIK, ŚWIECA 2012).

Kolejny nurt koncentruje się na badaniach ruchu turystycznego na wybranych obszarach. Studia dotyczyły oceny warunków rozwoju ruchu turystycznego w regionie (BRZEZIŃSKA-WÓJCIK, ŚWIECA, TUCKI 2009), w Muzeum Pojezierza Łęczyńsko-Włodawskiego (KRUKOWSKA 2004) oraz na terenie parków narodowych regionu lubelskiego (SKOWRONEK, ŚWIECA, TUCKI, KRUKOWSKA 2007, ŚWIECA i in. 2013). 
Czwarty nurt odnosi się do wykorzystania zasobów w kreowaniu produktów turystycznych. Oceniono stan i perspektywy rozwoju produktów turystycznych: na Płaskowyżu Nałęczowskim - „Kraina Zdrowia”, „Sielska Kraina" (KRUKOWSKA 2011, SKOWRONEK 2011) oraz na Roztoczu w kontekście turystyki edukacyjnej i przyrodniczej (BRZEZIŃSKA-WÓJCIK, ŚWIECA 2014; w druku). Analizowano wpływ społeczności lokalnych na rozwój obszarów wiejskich Lubelszczyzny na przykładzie „Krainy Rumianku” (SKOWRONEK, KRUKOWSKA, TUCKI 2011). Scharakteryzowano wielkość i zróżnicowanie bazy noclegowej jako determinanty popytu turystycznego w regionie lubelskim (TUCKI, SKOWRONEK, KRUKOWSKA 2012). Podejmowano zagadnienie innowacyjności oferty turystycznej województwa w zakresie: turystyki przyrodniczej (geoturystyki) (BRZEZIŃSKA-WÓJCIK 2012), turystyki kulturowej (SKOWRONEK 2012) oraz aktywnej (KRUKOWSKA 2012).

Następny nurt obejmuje studia nad percepcją przestrzeni turystycznej. Dotyczyły one miasta Lublina (BRZEZIŃSKA-WÓJCIK, ŚWIECA, ROMAŃSKA 2009, SKOWRONEK, BRZEZIŃSKA-WÓJCIK, KRUKOWSKA 2009, ŚWIECA, SKOWRONEK, BRZEZIŃSKA-WÓJCIK, KRUKOWSKA 2009, TUCKI 2013).

Szósty aspekt działalności koncentruje się wokół zmian środowiska spowodowanych rozwojem turystyki i rekreacji. Analizowano przeobrażenia krajobrazu wywołane użytkowaniem rekreacyjnym $\mathrm{w}$ gminie Włodawa (KRUKOWSKA, SKOWRONEK, KRUKOWSKI 2003, 2010) oraz w Kazimierskim Parku Krajobrazowym (SKOWRONEK, WOŁOSZYN 2004). Na przykładzie Kazimierskiego Parku Krajobrazowego przedstawiono znaczenie planowania i zarządzania w turystyce (WOŁOSZYN, SKOWRONEK 2007).

Stosunkowo nowy poligon badawczy stanowią rozważania dotyczące postaw społeczności lokalnej wobec rozwoju turystyki w województwie lubelskim (TUCKI, SOSZYŃSKI 2013, TUCKI, SKOWRONEK, KRUKOWSKA 2013). Analizą objęto miejską gminę Kazimierz Dolny oraz miejsko-wiejską gminę Zwierzyniec. Studia wykazały, że mieszkańcy nastawieni są proturystycznie w skali lokalnej i regionalnej. Odnosząc uzyskane rezultaty badań do pięciostopniowego modelu G.V. DOXEYA (1975), etap rozwoju turystyki na analizowanych obszarach można uznać za początkowy (etap eksploracji/wprowadzenia), w którym dominuje jeszcze faza euforii.

Istotną cechą większości opracowań przygotowanych w ostatnich latach jest ich wyraźny wymiar aplikacyjny. Wynika on $z$ nawiązania ścisłej i owocnej współpracy z jednostkami samorządowymi oraz podmiotami branży turystycznej. Dobrym przykładem są w tym przypadku opracowania wynikające $\mathrm{z}$ udziału pracowników w stażach i ekspertyzach, m.in. w LOT 
„Kraina Lessowych Wąwozów”, Lubelskiej Regionalnej Organizacji Turystycznej, Departamencie Gospodarki i Innowacji Urzędu Marszałkowskiego. Przedsięwzięcia tego typu zaowocowały opracowaniami prezentującymi rozwój produktów turystycznych w regionie lubelskim, bądź też analizującymi wpływ działań lokalnych społeczności i organizacji turystycznych na rozwój przedsiębiorczości i gospodarki turystycznej (KRUKOWSKA 2011, SKOWRONEK 2011, SKOWRONEK, KRUKOWSKA, TUCKI 2011, 2012, BRZEZIŃSKAWÓJCIK i in. 2011, BRZEZIŃSKA-WÓJCIK 2012, KRUKOWSKA 2012, SKOWRONEK 2012, TUCKI 2013).

\section{Podsumowanie}

Dotychczasowa działalność badawcza nad zjawiskami turystyczno-rekreacyjnymi wskazuje, że w badaniach podejmowanych przez pracowników Zakładu Geografii Regionalnej i Turyzmu Uniwersytetu Marii Curie-Skłodowskiej w Lublinie podstawowe znaczenie miały zagadnienia z zakresu uwarunkowań rozwoju tych zjawisk.

Aktywność badawcza pracowników Zakładu w zakresie turystyki obejmuje kilka nurtów. Najwięcej opracowań dotyczy badań nad uwarunkowaniami rozwoju turystyki w zakresie zasobów przyrodniczych i kulturowych, potencjału turystycznego oraz zagospodarowania turystycznego. Na tym tle podejmowano zagadnienia dotyczące natężenia ruchu turystycznego, funkcji turystycznej, percepcji przestrzeni turystycznej oraz regionalizacji turystycznej.

Na podkreślenie zasługuje również współpraca geografów z jednostkami samorządowymi, organizacjami i stowarzyszeniami w zakresie przygotowywania materiałów promocyjnych, ekspertyz, nowych produktów turystycznych, strategii rozwoju turystyki w województwie lubelskim, szkoleń oraz staży organizowanych przez podmioty administracji państwowej i samorządowej.

Praktyczną egzemplifikację badań naukowych nad potencjałem turystycznym regionu lubelskiego stanowią propozycje wydzielenia regionów turystycznych oraz regionalnych produktów turystycznych.

W najnowszych pracach zespołu podkreślana jest rola turystyki jako skutecznego narzędzia podnoszącego konkurencyjność i innowacyjność regionalnej gospodarki turystycznej. Zwraca się uwagę na przygotowanie odpo- 
wiedniego produktu turystycznego o określonej wysokiej jakości, jako elementu zwiększającego zainteresowanie regionem u potencjalnych turystów. $\mathrm{W}$ przyszłości istotną rolę $\mathrm{w}$ rozwoju turystyki $\mathrm{w}$ regionie lubelskim powinny odgrywać klastry, definiowane jako nowoczesne systemy zintegrowanych sieci powiązań podmiotów gospodarczych i organizacji wspierających. W perspektywie nieodzowna będzie potrzeba podejmowania systemowych badań podkreślających specyfikę wzajemnych zależności pomiędzy regionalnymi zasobami, przedsiębiorstwami turystycznymi, instytucjami naukowo-badawczymi, organizacjami samorządowymi oraz innymi podmiotami gospodarki.

\section{LITERATURA}

ANASIEWICZ I., BURACZYŃSKI J., KĘSIK A., MICHNA E., WARAKOMSKI W., 1967, Projekt inwentaryzacji wybranych szlaków turystycznych Polski południowo-wschodniej, UMCS, Lublin.

BRZEZIŃSKA-WÓjCIK T., 2009, Progi skalne w korytach rzek strefy krawędziowej Roztocza jako ważne obiekty w turystyce poznawczej, „Roztoczańskie Spotkania”, VI, Roztoczański Park Narodowy, Zwierzyniec, s. 181-195.

BRZEZIŃSKA-WÓJCIK T., 2012, Produkty geoturystyczne w województwie lubelskim jako przykład działań innowacyjnych, poszerzajacych dotychczasowa oferte turystyczna regionu, [w:] D. Jegorow, A. Niedużak (red.), Wptyw sektora $B+R$ na wzrost polskiej konkurencyjności polskiej gospodarki poprzez rozwój innowacji, 1, Chełmskie Stowarzyszenie Rozwoju Społeczno-Gospodarczego CIVIS, Chełm, s. 127-148.

BRZEZIŃSKA-WÓJCIK T., BARANOWSKA M., 2012, Stan turystyki konnej w województwie lubelskim w kontekście uwarunkowań przyrodniczych, „Polish Journal of Sport and Tourism” 19, 4, s. 256-270.

BRZEZIŃSKA-WÓJCIK T., HARASIMIUK M., 2009, Dziedzictwo geologiczne Roztocza - problemy ochrony i udostepnienia turystycznego, [w:] R. Reszel, T. Grabowski (red.), Roztocze - region pogranicza przyrodniczo-kulturowego. Materiaty polsko-ukraińskiej konferencji naukowej „35 lat ochrony dziedzictwa przyrodniczo-kulturowego Roztocza - regionu pogranicza", Wyd. Roztoczański Park Narodowy, Zwierzyniec, s. 27-42.

BRZEZIŃSKA-WÓJCIK T., SKOWRONEK E., 2009, Potencjat turystyczny Roztocza Tomaszowskiego na przykładzie gminy miejsko-wiejskiej Krasnobród, „Annales UMCS”, B, 64, 1, s. 171-199.

BRZEZIŃSKA-WÓJCIK T., ŚWIECA A., 2011, Potencjat turystyczny Wyniostości Gietczewskiej (środkowo-wschodnia Polska), „Polish Journal of Sport and Tourism”, 18, s. 244-255.

BRZEZIŃSKA-WÓJCIK T., ŚWIECA A., 2012, Typologia funkcjonalna przestrzeni turystycznej miasta Lublina. Zeszyty Naukowe Uniwersytetu Szczecińskiego, 738, „Ekonomiczne Problemy Turystyki”, 4, 20, s. 173-187.

BRZEZIŃSKA-WÓJCIK T., ŚWIECA A., 2014 (w druku), Stan i perspektywy rozwoju produktów turystycznych na Roztoczu w kontekście turystyki edukacyjnej i przyrodniczej, „Zeszyty Naukowe Uniwersytetu Szczecińskiego".

BRZEZIŃSKA-WÓJCIK T., ŚWIECA A., KOCIUBA W., 2007, Przyrodnicze uwarunkowania rozwoju turystyki na Roztoczu, [w:] M. Żabka, R. Kowalski (red.), Przyroda a turystyka we wschodniej Polsce, Wyd. Akademii Podlaskiej, Siedlce, s. 13-34. 
BRZEZIŃSKA-WÓJCIK T., ŚWIECA A., OSMÓLSKA B., 2006, Obiekty sakralne jako element atrakcyjności turystycznej w gminach przygranicznych województwa lubelskiego, [w:] G. Godlewski, M. Bochenek (red.), Walory turystyczne Euroregionu Bug jako czynnik aktywności gospodarczej i integracji spoteczno-kulturowej w zjednoczonej Europie, AWF, Biała Podlaska, s. 176-195.

BRZEZIŃSKA-WÓJCIK T., ŚWIECA A., ROMAŃSKA M., 2009, Miasto Lublina w ocenie studentów, [w:] J. Styk, A. Świeca (red.), Przestrzeń Lublina w ocenach jej użytkowników, „Stare i Nowe Struktury Społeczne w Polsce", VIII, Wyd. UMCS, Lublin, s. 123-138.

BRZEZIŃSKA-WÓJCIK T., ŚWIECA A., TUCKI A., 2009, Możliwości rozwoju turystyki w województwach wschodniej Polski, „Polish Journal of Sport and Tourism” 16, 2, s. 65-84.

BRZEZIŃSKA-WÓJCIK T., GRABOWSKI T., MOSKAL A., PAWŁOWSKI A., WIECHOWSKA I., 2011, Część opisowa do mapy: Szlak geoturystyczny Roztocza Środkowego. Informator - mapa turystyczna $1: 50$ 000, Kartpol s.c., Lublin.

DOXEY G.V., 1975, A causation theory of visitor-resident irritants: Methodology and research inferences. The Impact of Tourism, Travel Research Association Sixth Annual Conference Proceedings, San Diego, CA, s. 57-72.

GOŁEMBSKI G. (red.), 1999, Regionalne aspekty rozwoju turystyki, Wyd. Nauk. PWN, Warszawa-Poznań.

KRĄPIEC M., JANKOWSKI L., MARGIELEWSKI W., BURACZYŃSKI J., KRĄPIEC P., URBAN J., WYSOCKA A., DANEK M., SZYCHOWSKA-KRĄPIEC E., BOLKA M., BRZEZIŃSKA-WÓJCIK T., CHABUDZIŃSKI Ł., WAŚKOWSKA A., 2011, Geopark Kamienny Las na Roztoczu - koncepcja geoochrony wraz z wykonaniem dokumentacji i badań naukowych niezbędnych dla funkcjonowania tej formy ochrony, AGH, Kraków.

KRUKOWSKA R., 2004, Ruch turystyczny w Muzeum Pojezierza Łęczyńsko-Wtodawskiego, [w:] Z. Michalczyk (red.), Badania geograficzne w poznawaniu środowiska, Wyd. UMCS, Lublin, s. 676-681.

KRUKOWSKA R., 2007, Użytkowanie turystyczne jezior Pojezierza Łęczyńsko-Wtodawskiego, [w:] W. Kurek, R. Faracik (red.), Studia nad turystyka, Prace Geograficzne i Regionalne, IGiGP UJ, Kraków, S. 77-84.

KRUKOWSKA R., 2009, Pojezierze Łęczyńsko-Wtodawskie - funkcja turystyczna regionu, „Folia Touristica”, 21, s. 165-184.

KRUKOWSKA R., 2010, Przestrzeń turystyczna Pojezierza Łęczyńsko-Wtodawskiego, [w:] M. Durydiwka, K. Duda-Gromada (red.), Przestrzeń turystyczna - czynniki, różnorodność, zmiany, Uniwersytet Warszawski, Warszawa, s. 271-278.

KRUKOWSKA R., 2011, Tworzenie sieciowych produktów turystycznych na przyktadzie "Sielskiej krainy" w Krainie Lessowych Wąwozów, [w:] Nauka <=> Biznes, Zbiór raportów badawczych opracowanych przez pracowników naukowych i naukowo-dydaktycznych - przedstawicieli lubelskiego środowiska naukowego, Chełmskie Stowarzyszenie Rozwoju Społeczno-Gospodarczego CIVIS, Chełm, s. 415-449.

KRUKOWSKA R., 2012, Innowacyjne działania promocyjne w zakresie rozwoju turystyki aktywnej w województwie lubelskim, [w:] D. Jegorow, A. Niedużak (red.), Wptyw sektora B+R na wzrost polskiej konkurencyjności polskiej gospodarki poprzez rozwój innowacji, 1, Chełmskie Stowarzyszenie Rozwoju Społeczno-Gospodarczego CIVIS, Chełm, s. 83-97.

KRUKOWSKA R., KRUKOWSKI M., 2009, Ocena atrakcyjności turystycznej Pojezierza Łęczyńsko-Wtodawskiego, „Annales UMCS” B, 64, 1, s. 77-96.

KRUKOWSKA R., SKOWRONEK E., 2003, Uwarunkowania przyrodnicze rozwoju turystyki w gminie Wtodawa, [w:] R. Cieśliński, K. Piech (red.), Miejsce i rola turystyki w strategii społeczno-gospodarczej województw wschodniej Polski, ZWWF w Białej Podlaskiej, s. 143-151.

KRUKOWSKA R., SKOWRONEK E., 2009, Walory przyrodnicze jako podstawa rozwoju turystyki w gminie Wtodawa, „Polish Journal of Sport and Tourism”, 16, 1, s. 15-22.

KRUKOWSKA R., ŚWIECA A., 2008, Osadnictwo letniskowe jedna z form wykorzystania turystycznego obszarów wypoczynkowych na przykładzie Pojezierza Łęczyńsko-Wtodawskiego, [w:] J. Wyrzykowski 
(red.), Uwarunkowania rozwoju turystyki zagranicznej w Europie Środkowej i Wschodniej, Turystyka w środowisku geograficznym, 10, IGiRR UW, Wrocław, s. 175-184.

KRUKOWSKA R., SKOWRONEK E., KRUKOWSKI M., 2003, Zmiany w krajobrazie gminy Wtodawa zachodzace pod wptywem użytkowania rekreacyjnego, „Problemy Ekologii Krajobrazu”, XI, s. 45-54.

KRUKOWSKA R., SKOWRONEK E., KRUKOWSKI M., 2010, Wptyw użytkowania rekreacyjnego na przemiany krajobrazu gminy Wtodawa w latach 1980-2005, „Problemy Ekologii Krajobrazu”, XXVII, s. 217-223.

LANKFORD S.V., HOWARD D., 1994, Developing a tourism impact attitude scale, "Annals of Tourism Research", 21, 1, s. 121-139.

NOWACKA M., 1984, Zasady kwalifikowania terenu na potrzeby rekreacji, Wyd. UMCS, Lublin.

NOWOSAD M., 1989, Szlaki turystyczne okolic Lublina, Zarząd Wojewódzki PTTK, Lublin.

SKOWRONEK E., 2005, Wptyw dziatalności gospodarczej Ordynacji Zamojskiej na kształt dziedzictwa przyrodniczego i kulturowego Zamojszczyzny, [w:] E. Skowronek (red.), Wptyw dziatalności gospodarczej wielkich majątków ziemskich na stan wspótczesny dziedzictwa przyrodniczego i kulturowego, Wyd. UMCS, Lublin, s. 19-37.

SKOWRONEK E., 2011, Uwarunkowania rozwoju oferty turystycznej Krainy Lessowych Wąwozów na przykładzie produktu "Kraina Zdrowia", [w:] Nauka <=> Biznes, Zbiór raportów badawczych opracowanych przez pracowników naukowych i naukowo-dydaktycznych - przedstawicieli lubelskiego środowiska naukowego, Chełmskie Stowarzyszenie Rozwoju Społeczno-Gospodarczego CIVIS, Chełm, s. 62-92.

SKOWRONEK E., 2012, Budowanie innowacyjności oferty turystycznej województwa lubelskiego w zakresie turystyki kulturowej, [w:] D. Jegorow, A. Niedużak (red.), Wptyw sektora B+R na wzrost polskiej konkurencyjności polskiej gospodarki poprzez rozwój innowacji, 1, Chełmskie Stowarzyszenie Rozwoju Społeczno-Gospodarczego CIVIS, Chełm, s. 99-126.

SKOWRONEK E., WOŁOSZYN W., 2004, Turystyka jako czynnik przemian krajobrazu kulturowego w Kazimierskim Parku Krajobrazowym, [w:] M. Kucharczyk (red.), Wspótczesne problemy ochrony krajobrazu, Zarząd Zespołu Lubelskich Parków Krajobrazowych, Lublin, s. 107-117.

SKOWRONEK E, WOŁOSZYN W., 2006, Socio-economic factors effect on the cultural landscape development of the Roztocze region, [w:] E. Skowronek, W. Wołoszyn, T. Speck, K.M. Born (eds.), Cultural Landscapes of the Lublin Upland and Roztocze, Wyd. Kartpol s.c., Lublin, s. 81-97.

SKOWRONEK E., BRZEZIŃSKA-WÓJCIK T., KRUKOWSKA R., 2009, Oceny przestrzeni spotecznej Lublina, [w:] J. Styk (red.), Przestrzeń antropogeniczna miasta Lublina. Waloryzacja - wytwarzanie - użytkowanie, "Stare i Nowe Struktury Społeczne w Polsce”, IX, Wyd. UMCS, Lublin, s. 81-93.

SKOWRONEK E., KRUKOWSKA R., TUCKI A., 2011, Wptyw społeczności lokalnych na rozwój obszarów wiejskich Lubelszczyzny na przyktadzie Krainy Rumianku, [w:] A. Rapacz (red.), Gospodarka turystyczna w regionie. Przedsiębiorstwo - samorząd - wspótpraca, „Prace Naukowe Uniwersytetu Ekonomicznego", 157, s. 525-534.

SKOWRONEK E., KRUKOWSKA R., TUCKI A., 2012, Innowacyjność i rozwój oferty Uzdrowiska Nałęczów S.A. jako odpowiedź na zapotrzebowanie rynku turystyki zdrowotnej, "Zeszyty Naukowe Uniwersytetu Szczecińskiego" 698, „Ekonomiczne Problemy Usług”, 83: Popyt Turystyczny, s. 495-508.

SKOWRONEK E., ŚWIECA A., TUCKI A., 2005, The importance of the Lublin region national parks in the development of tourism in the Polish-Ukrainian borderland, [w:] Book of abstracts, The 11-th International Symposium on Society and Resource Management (ISSRM 2005), Ostersund, s. 68-69.

SKOWRONEK E., WOJCIECHOWSKI K.H., ŚWIECA A., 2006, The history of the ethnic transformations of the Lublin Region, [w:] E. Skowronek, W. Wołoszyn, T. Speck, K.M. Born (eds), Cultural Landscapes of the Lublin Upland and Roztocze, Kartpol s.c., Lublin, s. 33-47.

SKOWRONEK E., ŚWIECA A., TUCKI A., KRUKOWSKA R., 2007, Rola parków narodowych regionu lubelskiego w rozwoju ruchu turystycznego na obszarach pogranicza polsko-ukraińskiego, [w:] M. Żabka, R. Kowalski (red.), Przyroda a turystyka we wschodniej Polsce, Wyd. Akademii Podlaskiej, Siedlce, s. 35-52. 
SUPERSON J., BRZEZIŃSKA-WÓJCIK T., CHABUDZIŃSKA B., SKULSKA A., 2013 (w druku), Funkcja turystyczna Zamościa w świetle analizy wybranych elementów zagospodarowania turystycznego i natężenia ruchu turystycznego w latach 1999-2011, „Folia Turistica”.

ŚWIECA A., 2006, Aktywne formy wypoczynku, [w:] A. Świeca, K. Kałamucki (red.), Turystyka aktywna i jej rozwój na Roztoczu - regionie pogranicza, Kartpol s.c., Lublin, s. 13-20.

ŚWIECA A., 2013, Potencjat turystyczny regionu lubelskiego. Ekspertyza naukowa. Projekt systemowy: „Kapitat intelektualny Lubelszczyzny. 2010-2013”, Lublin.

ŚWIECA A., BRZEZIŃSKA-WÓJCIK T., 2009, Zasoby turystyczne i możliwości ich wykorzystania na obszarze miasta i gminy Nałęczów oraz gminy Wojciechów, „Annales UMCS” B, 64, 1, s. 145-170.

ŚWIECA A., BRZEZIŃSKA-WÓJCIK T., 2010, Nauka i dydaktyka w geografii turyzmu oraz w turystyce i rekreacji, [w:] S. Tanaś (red.), Nauka i dydaktyka w turystyce i rekreacji, Łódzkie Towarzystwo Naukowe, Łódź, s. 201-212.

ŚWIECA A., BRZEZIŃSKA-WÓJCIK T., 2011, Zróżnicowanie przestrzeni turystycznej miasta Lublina, [w:] B. Włodarczyk (red.), Turystyka. Księga jubileuszowa w 70. rocznicę urodzin Profesora Stanistawa Liszewskiego, Wyd. Uniwersytetu Łódzkiego, Łódź, s. 231-244.

ŚWIECA A., BRZEZIŃSKA-WÓJCIK T., 2013, Przestrzeń turystyczno-rekreacyjna Lubelszczyzny w świetle dotychczasowych opracowań geograficznego ośrodka lubelskiego, [w:] R. Pawlusiński (red.), Wspótczesne uwarunkowania i problemy rozwoju turystyki, IGiGP UJ, Kraków, s. 315-328.

ŚWIECA A., TUCKI A., 2007, Uwarunkowania geograficzne i perspektywy rozwoju turystyki na przyktadzie wybranego obszaru Pojezierza Łęczyńsko-Wtodawskiego, [w:] J. Bergier, M. Stelmach (red.), Kierunki rozwoju turystyki w województwie lubelskim, Wyd. PWSZ w Białej Podlaskiej, Biała Podlaska, s. $91-107$.

ŚWIECA A., BRZEZIŃSKA-WÓJCIK T., KOCIUBA W., 2009, Charakterystyka przestrzeni przyrodniczej terytorium miasta Lublina, [w:] J. Styk (ed.), Przestrzeń antropogeniczna miasta Lublina. Waloryzacja wytwarzanie - użytkowanie, "Stare i Nowe Struktury Społeczne w Polsce”, IX, Wyd. UMCS, Lublin, s. 13-34.

ŚWIECA A., BRZEZIŃSKA-WÓJCIK T., GRABOWSKI T., KAŁAMUCKI K., KRUKOWSKA R., TUCKI A., 2013, Turystyka i edukacja w Roztoczańskim Parku Narodowym i w jego otulinie, [w:] R. Reszel, T. Grądziel (red.), Roztoczański Park Narodowy - przyroda i człowiek, Wyd. RPN, Zwierzyniec, s. 219-230.

ŚWIECA A., KRUKOWSKA R., BRZEZIŃSKA-WÓJCIK T., 2008, Uwarunkowania przyrodnicze $i$ kulturowe rozwoju turystyki w gminach nadbużańskich Włodawa i Wola Uhruska, [w:] M.S. Zięba (ed.), Nasz Bug. Tworzenie warunków dla rozwoju obszarów przygranicznych Polski, Ukrainy i Białorusi poprzez waloryzację $i$ ochronę dziedzictwa naturalnego i kulturowego, Wyd. KUL, Lublin, s. 347-364.

ŚWIECA A., KRUKOWSKA R., TUCKI A., 2007, Possibilities for the Development of Tourism in the Lublin Region, [w:] G. Godlewski, M. Bochenek (eds), Tourism - Theory - Conditiones - Experiences, Wyd. AWF, Biała Podlaska, s. 69-98.

ŚWIECA A., SKOWRONEK E., BRZEZIŃSKA-WÓJCIK T., KRUKOWSKA R., 2009, Ocena przestrzeni turystycznej Lublina przez turystów i mieszkańców, „Polish Journal of Sport and Tourism” 16, 4, s. 235-246.

ŚWIECA A., KRUKOWSKA R., TUCKI A., SKOWRONEK E., BRZEZIŃSKA-WÓJCIK T., KOCIUBA W., JÓŹWIK M.J., 2012, Possibilities of tourist use of natural and cultural resources in the Lublin region - case study, "Annales UMCS" B, LXVII, 1, s. 219-244.

TUCKI A., 2004, Próba oceny atrakcyjności turystycznej obszaru na przykładzie gminy Ludwin, [w:] Z. Michalczyk (red.), Badania geograficzne w poznawaniu środowiska. Wyd. UMCS, Lublin, s. 714-719.

TUCKI A., 2007a, Regionalne aspekty rozwoju turystyki na przykładzie województwa Lubelskiego, [w:] W. Kurek, R. Faracik (ed.), Studia nad turystyka. Prace Geograficzne i Regionalne: Geograficzne, ekonomiczne i społeczne aspekty turystyki, IGiGP UJ, Kraków, s. 267-279.

TUCKI A., 2007b, Uwarunkowania funkcjonalne rozwoju gospodarki turystycznej w regionie lubelskim, [w:] J. Wyrzykowski (ed.), Rola turystyki w gospodarce regionu, WSH, Monografie, Wrocław, s. 68-79.

TUCKI A., 2009, Potencjat turystyczny regionu lubelskiego, „Annales UMCS” B, 64, 1, s. 11-31. 
TUCKI A., 2010a, Formy ochrony przyrody jako element atrakcyjności turystycznej na przykładzie regionu lubelskiego, „Problemy Ekologii Krajobrazu”, XXVII, s. 363-370.

TUCKI A., 2010b, Zastosowanie Internet Technology jako narzędzia promocji na przykładzie wybranych gmin województwa lubelskiego, "Zeszyty Naukowe Uniwersytetu Szczecińskiego” 591, „Ekonomiczne Problemy Usług", 53, s. 269-277.

TUCKI A., 2010c, Propozycja regionalizacji turystycznej województwa lubelskiego, „Folia Turistica”, 21, s. $145-163$.

TUCKI A., 2012, Rola przywódcy w regionie turystycznym. Przykład Lokalnej Organizacji Turystycznej "Roztocze", [w:] B. Sawicki, A. Niziol, M. Obodyński (red.), Rola organizacji pozarządowych w rozwoju i promocji turystyki, Wyd. Uniwersytetu Rzeszowskiego, Rzeszów, s. 193-203.

TUCKI A., 2013, Wizerunek i atrakcyjność turystyczna Lublina, Raport z badania przeprowadzonego na terenie lublina w dniach 15.06-09.09.2013 r., Lublin.

TUCKI A., HADZIK A., 2013, Analiza możliwości rozwoju turystyki zdrowotnej w województwie lubelskim w kontekście zintensyfikowanej inteligentnej specjalizacji regionu w dziedzinie ustug medycznych $i$ prozdrowotnych, Raport końcowy z badania dziedzinowego, Prefekta info, Lublin.

TUCKI A., SOSZYŃSKI D., 2013, Postawy społeczności lokalnej miasta Kazimierz Dolny wobec rozwoju turystyki, „Problemy Ekologii Krajobrazu”, XXXIV, s. 245-252.

TUCKI A., ŚWIECA A., 2008, The role of local government in the development of tourism as exemplified by the Lublin region, [w:] J. Wyrzykowski (ed.), Conditions of the foreign tourism development in Central and Eastern Europe, ,"Tourism in Geographical Environment", 10, Wrocław, s. 493-509.

TUCKI A., SKOWRONEK E., KRUKOWSKA R., 2012, Wielkość i zróżnicowanie bazy noclegowej jako determinanta popytu turystycznego w regionie lubelskim, "Zeszyty Naukowe Uniwersytetu Szczecińskiego" 699, „Ekonomiczne Problemy Usług", 84, s. 383-396.

TUCKI A., SKOWRONEK E., KRUKOWSKA R., 2013, Ocena postaw społeczności lokalnej do rozwoju turystyki na przykładzie Zwierzyńca, „Prace Naukowe Uniwersytetu Ekonomicznego”, 304, s. 347-357.

TUCKI A., SKOWRONEK E., KRUKOWSKA R., ŚWIECA A., 2011, Rola lokalnych organizacji w rozwoju przedsiębiorczości i gospodarki turystycznej na przykładzie Lokalnej Organizacji Turystycznej "Kraina Lessowych Wąwozów", [w:] A. Rapacz (red.), Gospodarka turystyczna w regionie. Przedsiębiorstwo samorząd - wspótpraca, „Prace Naukowe Uniwersytetu Ekonomicznego”, 157, s. 535-545.

Wilgat T., 1956, Pojezierze Łęczyńsko-Włodawskie jako teren wycieczek geograficznych, "Czasopismo Geograficzne", 27, 1, s. 99-118.

Wilgat T., 1962, Zagadnienie strefy wypoczynkowej Lublina, [w:] Przewodnik VII Ogólnopolskiego Zjazdu PTG w Gdańsku, cz. I, Gdańsk, s. 23-27.

Wilgat T. (red.), 1963, Polesie Lubelskie. Materiaty z sesji naukowej Polskiego Towarzystwa Geograficznego, Wyd. Lubelskie, Lublin.

WILGAT T., 1971, Zagadnienia terenów rekreacyjnych w województwie lubelskim, „Miasto”, 22, 3, s. 12-17.

WOJCIECHOWSKI K.H., 1976, Pojezierze Łęczyńsko-Wtodawskie, Wojewódzki Ośrodek Informacji Turystycznej w Lublinie.

WoŁOSZYN W., SKOWRONEK E., 2007, Tourism Planning and Management in Kazimierz Landscape Park, Poland, [w:] Z. Roca, T. Spek, T. Terkenli, T. Plieninger, F. Höchtl (eds), European Landscapes and Lifestyles: The Mediterranean and Beyond, Edições Universitárias Lusófonas, Lizbon, s. 375-383.

ZGŁOBICKI W., BRZEZIŃSKA-WÓJCIK T., GAWRYSIAK L., HARASIMIUK M., 2007, Stanowiska geomorfologiczne regionu lubelskiego jako narzędzie rozwoju geoturystyki, [w:] M. Harasimiuk, T. Brzezińska-Wójcik, R. Dobrowolski, P. Mroczek, J. Warowna (red.), Budowa geologiczna regionu lubelskiego i problemy ochrony litosfery, Wyd. UMCS, Lublin, s. 271-277. 


\section{TOURISM RESEARCH IN THE LUBLIN REGION: A LITERATURE REVIEW}

Key words: tourism, methods, research results, Lublin region

\section{Summary}

The article examines the current state of research on the tourism development in the Lublin region. Publication has been summarized taking into account tourist and recreational space of Lublin region, prepared by researchers of the Department of Regional Geography and Tourism UMCS. Research activity includes several trends. The studies undertaken were essential issues of the determinants of the development of different tourism forms. The attention paid to the issues of inventory and valuation of natural and cultural resources. Attempts functional analysis of Lublin region tourist space, the perception of tourist space, the touristic regionalization and development of tourist products. Particularly noteworthy effects of cooperation with local government units, organizations and associations. 